\title{
Mapuche Language
}

National Cancer Institute

\section{Source}

National Cancer Institute. Mapuche Language. NCI Thesaurus. Code C153836.

A language isolate spoken in south-central Chile and west central Argentina by the Mapuche people. 